\title{
China in Africa
}

A Limited Conquest

François Lafargue

\section{CpenEdition}

Journals

Electronic version

URL: http://journals.openedition.org/chinaperspectives/4778

DOI: $10.4000 /$ chinaperspectives. 4778

ISSN: 1996-4617

\section{Publisher}

Centre d'étude français sur la Chine contemporaine

\section{Printed version}

Date of publication: 1 April 2009

Number of pages: 80-86

ISSN: 2070-3449

\section{Electronic reference}

François Lafargue, "China in Africa », China Perspectives [Online], 2009/1 | 2009, Online since 01 April 2011, connection on 10 December 2020. URL : http://journals.openedition.org/chinaperspectives/ 4778 ; DOI : https://doi.org/10.4000/chinaperspectives.4778

(C) All rights reserved 


\title{
China in Africa:
}

\section{A Limited Conquest}

\author{
FRANCOIS LAFARGUE
}

\begin{abstract}
The economic and diplomatic presence of the People's Republic of China (PRC) in Africa continues to generate commentary and analyses that are often unflattering, and there is no lack of argument to denounce its negative effects. However, a detailed analysis of the situation reveals quite a different reality. While it is undeniable that China's influence in Africa has grown, its economic interests there remain limited.
\end{abstract}

$\mathrm{S}$ ince the beginning of the twenty-first century, China has become a major economic player in Africa due to its interest in the continent's deposits of raw materials and hydrocarbons. It is also concerned with forging a fruitful political partnership with Africa, which would give it a stronger influence within the international community.

China's presence in Africa can be gauged by the increase in bilateral trade, ${ }^{(1)}$ which went from $\$ 12.3$ billion in 2002 to $\$ 40$ billion in 2005 before climbing to $\$ 55.5$ billion the following year and to $\$ 72.9$ billion in 2007 .

Criticism of China's policy in Africa has become commonplace. China is accused of establishing colonial relations with Africa by importing the continent's raw materials ${ }^{(2)}$ while exporting value-added finished products. Chinese businesses also benefit from the situation of the yuan, a currency that is notoriously undervalued, while countries in the franc zone are penalised through the appreciation of the CFA franc, itself linked to the Euro. Chinese companies are also accused of engaging in all-out competition with African countries in third markets such as the European Union. The clothing industry in Morocco (which represents 45 percent of industrial jobs) has been made particularly vulnerable since cancellation of the Multi-Fibre Arrangement (MFA) on 1 January 2005 liberalised China-EU trade in this area. Similarly, the AGOA Agreements ${ }^{(3)}$ designed to encourage exports, especially of textiles, from African countries to the United States now seem much less attractive. These are not the only criticisms. Chinese conglomerates are also blamed for the shoddy workmanship of African infrastructure, the mediocre quality of traded goods, and the fact that their workforce is recruited from China and poorly paid. ${ }^{(4)}$ The profits made by Chinese entrepreneurs are also seldom reinvested locally. Beijing grants financial aid in a cavalier fashion without any concern for the solvency of its debtors. Indeed, during a meeting of G8 Finance Ministers in May
2007, Western countries publicly expressed concern that China's attitude was a contributing factor in the indebtedness of African states. In the words of German Finance Minister Peer Steinbrück, "We note that China has a growing interest in African resources (...), ${ }^{(5)}$ " which is leading it "to start all over again the very thing we were hoping to put an end to with our debt reduction program, namely, the overindebtedness of African countries." Finally, Chinese investment gives comfort to autocratic regimes such as those of José Dos Santos in Angola or Omar al-Bashir in Sudan. In 2007 these two states accounted for 47 percent of all China's imports from the African continent.

There is no shortage of arguments denouncing the negative impact of China's presence in Africa. Neo-colonialism is a term routinely used not only in Europe, but now also by African elites, former South African President Thabo Mbeki being a case in point. ${ }^{(6)} \mathrm{A}$ detailed analysis of the situation reveals a somewhat different picture, however. This article does not discuss the motivations the PRC may have for being in Africa, or its investment strategies, which have

1. Statistical data from the Ministry of Commerce of the People's Republic of China: http://www.mofcom.gov.cn/.

2. In 2006, according to a WTO report, "Statistics of international trade," p. 214, raw materials (hydrocarbons, wood, cotton) made up $90.5 \%$ of Chinese imports from Africa, with agricultural products making up $6.8 \%$.

3. The AGOA law (African Growth and Opportunity Act) adopted in 2000 aims to facilitate the access of African goods to the American market via preferential measures and to contribute thereby to the development of the local economies.

4. Lafargue François, "La Chine, une puissance en Afrique," Perspectives chinoises, 2005 $n^{\circ}$ 90, p. 3; "China's Presence in Africa," China Perspectives, No. 61, September-October 2005, pp. 2-9.

5. AFP wire service, 19 May 2007.

6. In December 2006, during the 14th National Congress of the South African Students Congress (SASCO) held in Cape Town, the South African President Thabo Mbeki declared that Africa should not have a colonial relationship with China by being a mere provider of raw materials. See also the contribution by Anabela Lemos and Daniel Ribeiro, "Mozambique: Taking Ownership or Just Changing Owners?" in Firoze Manji and Stephen Marks, African Perspectives on China in Africa, Nairobi and Oxford, 2007, p. 63. 
Table 1. Amount of trade in billions of dollars since 2000

\begin{tabular}{l|c|c|c|c|c|c|c|c}
\hline & \multicolumn{2}{|c|}{$\begin{array}{c}\text { Imports } \\
\text { from Africa }\end{array}$} & \multicolumn{2}{c}{$\begin{array}{c}\text { Exports } \\
\text { to Africa }\end{array}$} & \multicolumn{2}{c}{$\begin{array}{c}\text { Total } \\
\text { Trade }\end{array}$} & Change \\
& 2000 & 2007 & 2000 & 2007 & 2000 & 2007 & \\
\hline United States & 29 & 95.2 & 10.9 & 23.6 & 39.9 & 118.8 & $197 \%$ \\
\hline European Union & 73.1 & 162.2 & 57.7 & 138.1 & 130.8 & 300.3 & $\frac{129.6 \%}{600 \%}$ \\
\hline PRC & 5.56 & 36.36 & 4.9 & 36.5 & 10.4 & 72.86 & $600 \%$ \\
\hline
\end{tabular}

Source: WTO Report, International Trade Statistics, 2008 and 2000.

already been the subject of a number of studies. ${ }^{(7)}$ It does, however, indicate the need for a sense of proportion to understand China's growing influence in Africa, given that the scope of its economic interests there remains limited. The whole discourse on "China's conquest of Africa" must be seen in the context of a common yet largely unhelpful critique of Beijing's policy, which has little to do with the actual situation. In fact, China's African policies have subjected it to a barrage of criticism that is not always justified.

\section{China's place in Africa remains limited}

The PRC is today Africa's third most important trading partner. Table 1 shows that since 2000 the amount of trade between Africa and China has increased by 600 percent, compared with 197 percent for the United States and Africa. The increase in China-Africa exchanges is clearly indisputable, but it falls within a general increase in trade between Africa and the rest of the world (135 percent since 2000). In fact, the place of the PRC in the trade of African countries remains limited. Whilst the PRC is in the top rank of importers for several African nations, notably South Africa and Egypt, China's share of total imports from Africa amounted to 9.2 percent in 2006. According to World Trade Organisation (WTO) data ${ }^{(8)}$ in 2007, the PRC purchased 8.6 percent of the exports of African countries (that is, $\$ 36.53$ billion out of a total of $\$ 424$ billion), and remains far behind the European Union (38.2 percent) and the United States (22.4 percent). In 2000, the PRC bought 3.7 percent of the exports of African countries against 39 percent for the European Union and 19.7 percent for the United States. This increase in China-Africa trade can be explained not only by an increase in the volume of exchanges but also by the nature of Chinese imports, principally comprised of mining products and hydrocarbons, the value of which has sharply risen in recent years. In contrast, purchases made by the European Union are more diversified and include more agricultural products and manufactured goods, the value of which has remained basically stable. In 2006, hydrocarbons and mining products represented 85 percent of the PRC's imports from Africa against 63 percent for the European Union.

Similarly, financial figures indicate a need to put the Chinese presence into an appropriate perspective. ${ }^{(9)}$ In 2006, China's foreign direct investment (FDI) in Africa ${ }^{(10)}$ amounted to $\$ 2.56$ billion compared with $\$ 49.2$ million in 1990 and $\$ 491$ million in 2003. The growth in China's investments is clearly substantial, but in terms of stock and financial transfers, these investments remain very much below European and American capital investment in Africa. In 2005, United States investment stock in Africa amounted to $\$ 23$ billion dollars, ${ }^{(I)}$ with that of France totalling $\$ 15.55$ billion. ${ }^{(12)}$ Even in countries where China's presence is considered to be the most significant, such as Angola or Algeria, China's FDI remains well below that of the former colonial powers. In 2006, Africa received \$36 billion in foreign investment, of which $\$ 519$ million came from China that is, 1.4 percent - as against $\$ 2.1$ billion from the United

7. Cf. in particular Chris Alden, China in Africa, Partner, Competitor or Hegemon?, Zed Books, 2007.

8. World Bank Report, "International Trade Statistics," 2007 and 2000.

9. It is difficult to put an exact figure on Chinese investment in Africa, as some of this investment is made through Singapore and Hong Kong.

10. Mofcom, "Statistical Bulletin of China's Outward Foreign Direct Investment," 2006, p. 54

11. US Ministry of Trade, Official Bureau of Economic Analysis, http:// www.bea.gov/.

12. Bank of France "Balance des paiements et position extérieure," [Balance of Payments and External Position] Report for 2006. 
States. In 2007, there was a real spike in Chinese FDI in Africa, thanks to an exceptional event. This was the acquisition of 20 percent of the capital of the continent's leading bank, the Standard Bank in South Africa, by the Industrial and Commercial Bank of China (ICBC), China's leading bank, for $\$ 5.46$ billion.

In 2006, Africa was the destination of 1 percent of American investments abroad, 2.4 percent of French investment ${ }^{(13)}$ and 2.9 percent of China's (as against 43.4 percent in Asia). In February 2007, the Chinese Deputy Trade Minister, Wei Jianguo, announced that the value of China's approved investments in Africa now exceeded $\$ 6.6$ billion. While such a statement gives credence to the view that China has a stranglehold over Africa, it does little to explain how there can be such discrepancies with respect to the UNCTAD data, which indicate only half that amount. In the first place, investments that are actually committed are not always distinguished from projects that are merely approved. In particular, there is a kind of deliberate blurring of the boundaries between the investment of companies (both public and private) and aid money (loans and gifts) vouchsafed by the Chinese state, especially through the Exim Bank.

As to the public development aid (PDA) made available by Peking, it was estimated to total some $\$ 2.6$ billion in 2004 , ${ }^{(14)}$ and is expected to climb to $\$ 10$ billion in 2009 . By way of comparison, the net US aid ${ }^{(15)}$ to Africa was worth $\$ 4.5$ billion in 2007 (excluding debt relief). ${ }^{(16)}$ President Bush announced his intention to increase this aid to $\$ 9$ billion ${ }^{(17)}$ by 2010. For its part, the Committee for Development Aid (CDA) of the European Union (that is, 15 states) set its contribution at $\$ 18.6$ billion in 2006 . That same year, according to OECD data, Sub-Saharan Africa received $\$ 43.3$ billion in PDA. Of this sum, $\$ 11.4$ billion was for Nigeria, $\$ 2$ billion for Sudan and $\$ 2$ billion for the Democratic Republic of Congo. Some 72.5 percent of this total of $\$ 43$ billion was made up of contributions by CDA members for bilateral aid - and this does not include their participation in multilateral aid. China's aid to Africa therefore seems weak by comparison. It is not easy, however, to put a precise figure on it, as Beijing does not publish any official statistics and lumps together, under the term "aid," both zero-interest loans or loans with preferential rates of interest and donations. Such assistance is granted by several institutions, such as the China EximBank, the China Development Bank, or the Trade Ministry. One thing is certain, however: the economic and financial weight of China in Africa remains considerably below that of the former colonial powers and the United States.
China's policy has also been stigmatised owing to the granting of loans irrespective of the criteria determined by the OECD countries, in particular the Equator Principles. A case in point is Beijing granting, at the time of Hu Jintao's visit to Cameroon (30 January-1 February 2007), of several donations totalling 2.56 billion FCFA (that is, 3.9 million euros) and three loans amounting to 46.9 billion FCFA (71.5 million euros), half of which is to be allocated to the financing of a telecommunications project.

However, international institutions and the African press do not fail to point out the risks of this rapprochement with China. As the weekly Repères ${ }^{(18)}$ points out, Beijing's financial assistance sets up a mechanism for perpetual indebtedness. Cameroon had managed to fulfil the objectives imposed by international financial institutions, and by 2006 had reached the end point of the HIPC initiative. ${ }^{(19)}$ In partnership with its creditors, Yaoundé had undertaken efforts to partially discharge its public foreign debt, which had gone from 110.2 percent of GDP in 1997 to 60.2 percent in 2004. But the PRC's concern proved to be dangerous, since according to the OECD report African Economic Outlook, ${ }^{(20)}$ Cameroon's debt is expected to have climbed from 4.8 percent of GDP in 2007 to 6 percent in 2009. These charges laid against Beijing seem justified given that, unlike members of the CDA, the PRC prefers to give loans rather than donations. These loans are granted according to certain economic requirements, such as having a Chinese firm carry out the work. Nonetheless, it is not clear that such criticisms are well founded, since Beijing also regularly cancels debts owed to it, and for some debtors experiencing a significant increase in their GDP, the burden of servicing the debt is reduced. In March 2004, the PRC gave a loan of $\$ 2$ billion to Angola, which was mainly designed to finance infrastructure provided by Chinese

13. Bank of France, op.cit

14. Joshua Kurlantzick, "Beijing's Safari: China's Move into Africa and its Implications for Aid, Development and Governance," in Carnegie Endowment Policy Outlook No. 29, November 2006

15. These figures take no account of the contribution to multilateral bodies such as the UNPD or the UNHCR.

16. OECD, "Development Co-operation," 2007 Report.

17. Michael Fletcher, "Bush has quietly tripled aid to Africa," Washington Post, 31 December 2006

18. Repères, 7 February 2007, Yaoundé

19. The initiative in favour of Heavily Indebted Poor Countries (HIPC) is an international mechanism set up in 1996 with the goal of reducing the amount of debt of the poorest nations to a sustainable level. States benefiting from these arrangements must commit themselves to respecting strict measures of macro-economic stability. Once a certain benchmark has been reached, countries may apply for a higher level of aid.

20. OECD report, "African Economic Outlook," 2008, p. 217. 
Table 2. Import of petroleum from Africa in millions of barrels per day

\begin{tabular}{l|r|r|r|r}
\hline \hline & 2000 & 2007 & Growth & $\begin{array}{c}\text { Africa's } \\
\text { share of total } \\
\text { imports }\end{array}$ \\
\hline $\begin{array}{l}\text { United } \\
\text { States }\end{array}$ & 1.6 & 2.72 & $70 \%$ & $20 \%$ \\
$\begin{array}{l}\text { European } \\
\text { Union }\end{array}$ & 2.6 & 2.7 & $5 \%$ & $19.4 \%$ \\
\hline PRC & 0.33 & 1 & $220 \%$ & $25.95 \%$ \\
\hline
\end{tabular}

Source: BP, Statistical yearbook, 2001 and 2007.

"a huge contract illustrating the level of penetration of Chinese interests in Africa (...). It is the largest investment ever imagined by a Chinese player in Africa. The China National Petroleum Corporation has landed a $\$ 5$ billion contract to develop and promote the country's petroleum resources. Over the next three years it is due to extract crude oil from the area known as 'Agadem,' with proven reserves most recently estimated at 324 million barrels." ${ }^{(23)}$ This enormous contract could easily be seen, however, as a small consolation, considering that ESSO had already prospected the Agadem deposit several times since the 1960s, followed by the Malaysian company Petronas, all without success. Even if the size of the alleged reserves proves to be correct, they would represent just 0.3 percent of all of Africa's petroleum reserves.

Massive state subsidies allow Chinese companies to commit to huge projects without any guarantee of return on investment, while Western companies cannot afford the same luxury. These investments in the energy sector are no doubt determined more by political than financial concerns. Apart from Angola or Sudan, neither CNPC nor SINOPEC (China Petroleum and Chemical Corporation) have been in a position to gain oil concessions that offer much promise. In North Africa, too, results have been limited. In the area of hydrocarbons, the PRC is no more than a marginal client of the Maghrebi countries at the moment, since only 2.1 percent of Algerian oil exports go to China, compared with 5 percent to Libya. Overall, this region of North Africa is responsible for a mere 2 percent of Chinese oil imports. China is penalised by its distance from Mediterranean countries, and by the need for oil tankers to go through the Suez Canal, which is close to choking point today.
In Libya, where CNPC invested by taking advantage of the regime's isolation, Chinese companies face Anglo-Saxon competitors since the lifting of American sanctions in 2004. The first contracts awarded to Beijing gave it only very limited areas in which to prospect. The PRC even suffered an affront when the Taiwanese public company Chinese Petroleum Corporation was granted a license to operate in the Murzuk field 162 in the third round of bids in December 2006. In Angola, Chinese operations seem to have stalled since the beginning of 2007, as the gradual rehabilitation of President Dos Santos has enabled him to seek out Western investors such as Total. The United States remains the primary destination of Angola's petroleum, and no Chinese company is the main player in any of its operational off-shore sites. While Angola is sometimes presented ${ }^{(24)}$ in caricature mode as a "province" of China, the reality is much more complex. Like Algeria, Angola has been able to maintain close relations with other nations such as Portugal and the United States, ${ }^{(25)}$ and the PRC was only its fourth largest supplier in 2006.

Imports of minerals from Africa also feed criticism of China, which is now an important buyer of metals, wood products, and cotton in Africa. Once again, however, the former colonial powers and the United States still occupy a dominant position. In 2006, China's imports of minerals and metals from Africa amounted to $\$ 3.3$ billion as compared with $\$ 3.97$ billion for the United States, and $\$ 10.15$ billion for the European Union. ${ }^{(26)}$ In spite of sustained growth in its purchases from Africa, Beijing's share remains quite small. Moreover, these raw materials are mainly for the production of manufactured goods for exported to the European Union and not for local consumption. However, China's regular investments in Africa lead it to be blamed as the main cause of the rising cost of raw materials in the energy and agricultural sectors.

At first sight, the rise in the price of a barrel of oil can be explained by strong demand from Asia, given that consumption in China has jumped by 60 percent and in India by 15 percent since 2000. China is now the world's second largest consumer of petroleum after the United States, and India is ranked sixth. Nonetheless, this attributing of a crisis to Asian demand is only part of the picture, and while the press smug-

23. La Tribune, 3 June 2008.

24. Centre for Chinese Studies, "China's Interest and Activity in Africa's Construction and Infrastructure Sectors," Stellenbosch University.

25. Indira Campos and Alex Vines, "Angola and China: A Pragmatic Partnership," Working Paper, Chatham House, March 2008.

26. WTO, "International Trade Statistics," 2007, pp. 213-217. 
ly describes China as a "glutton," the reality is quite different. Consumption of oil in China is still at a very low level compared with Western countries, especially the United States. China's per capita oil consumption is less than 9 percent of that of the United States. In fact, oil consumption by America's 22 million inhabitants is not quite half that of China's 1.4 billion. In addition, in China's defence, petroleum's portion of the country's total energy consumption is just 20 percent, as against 40 percent in the United States, since in China petroleum is largely used for refining into petrol, with only limited use as fuel. Also worth noting is the fact that private ownership of motor vehicles in China is quite a recent phenomenon, which means that most of the vehicles in circulation consume less fuel than in the United States.

Finally, China's growth (11.1 percent in 2006, increasing to 11.4 percent in 2007), which is often held responsible for this thirst for energy, should be put into context. The country's increased growth in 2007 represents something in the order of $\$ 449$ billion, still below that of the US GNP growth rate (2.1 percent), although it is worth $\$ 649$ billion. Whereas China and India account for 38 percent of the world's population, they represent only 12 percent of world petroleum consumption, compared with 50 percent for the United States, Japan, and the European Union, which make up only 15 percent of the world's population. The countries of Africa, most of which have no hydrocarbon resources, are proving vulnerable to the rising cost of oil, as is the case with Senegal and Burkina Faso. Even those countries that are oil producers, such as Nigeria, are obliged, owing to their lack of refining capacity, to import a portion of their petrol at steadily rising cost. ${ }^{(27)}$ The charges brought against China seem, however, to be excessive.

The rise in the cost of hydrocarbons is causing an increase in the price of petrochemicals such as manure. In Europe, ${ }^{(28)}$ between October 2006 and September 2007 the price of a tonne of Baltic urea went up by 43 percent, and that of a tonne of ammonium sulphate by 66 percent. An inflation of this magnitude is one of the reasons for the food crisis currently being experienced by several African countries. ${ }^{(29)} \mathrm{But}$ this situation can also be explained by price increases (due to the increase in the price of raw materials such as hydrocarbons) resulting from the development of bio-fuels in industrialised countries and changes in eating habits in developing countries such as India and China. ${ }^{\left({ }^{30}\right)}$ Such arguments are often put forward with good reason, but they are quite unjust in stressing the extent of China's responsibility. In 2006, food imports from China reached $\$ 51.6$ billion compared with $\$ 19.5$ billion in 2000. ${ }^{(31)}$ During the same period, food imports from the United States rose from $\$ 69$ to 103 billion. With 19 percent of the world's population, China has only 5 percent of the world's arable land. Not only does China's portion of purchases on the world's food markets remain modest, the country actually manages to be an exporter of wheat and rice. According to FAO data, in 2006 China imported 1 million tonnes of rice (manufactured equivalent) and exported 1.4 million tonnes. Chinese imports of rice represent 4.1 percent of the world total. China's responsibility in the world food crisis should therefore be seen in a relative light, all the more so in that recent riots, particularly in Egypt, were caused by an increase in the price of bread, which resulted from an increase in wheat prices. China remains a net exporter of wheat, and its imports of maize are still modest, representing just 5.5 percent of purchases worldwide. In the same vein, and unlike some European countries and the United States, China has not engaged in a massive conversion of agricultural land to develop agro-fuels. ${ }^{(32)}$ The production of ethanol-based carburant (such as E10) remains at a very low level and is unlikely to increase substantially. Agricultural land is still primarily used for food-producing purposes.

\section{Conclusion}

At the 24 $4^{\text {th }}$ Africa-France Summit held in Cannes in February 2007, President Jacques Chirac hailed the positive role being played by China in Africa. At the closing press conference, the French President declared:

First of all, I warmly welcome what China has been doing in Africa, which is in my eyes a positive step. I had the opportunity to talk at length with President $\mathrm{Hu}$ Jintao, just before the African Summit in Peking,

27. Due to very limited refining capacity, the cost of petrol is increasing more rapidly than that of crude oil.

28. FAO, "Crop Prospects and Food Situation," November 2007.

29. According to FAO data, in the summer of 2008, 21 African countries experienced serious food insecurity.

30. In May 2008, US President George W. Bush claimed that the inflation of food prices was mainly due to the emergence of a middle class in India.

31. Idem, p. 214.

32. The use of agricultural land for producing agro-fuels is often cited as an aggravating factor in the rise in prices. Speaking at the FAO Summit in Rome in June 2008, President Lula stated that in Brazil, crops used for the production of ethanol take up a mere 1 percent of agricultural land, adding that "bio-fuels are not outlaws threatening the food security of the poorest nations." This interpretation is not shared by the World Bank. In the conclusion to its April 2008 policy note, "Rising Food Prices: Policy Options and World Bank Response," it points to the heavy responsibility of bio-fuels in the rising price of food. The OECD makes the same observation in "An economic assessment of the policies supporting bio-fuels," Martin von Lampe, July 2008. 
and we spoke a great deal about China-Africa relations, which are necessary, as Africa needs to have relations with the entire world, not just in the sphere of economics but also politically and culturally. The last two visits to Africa by Chinese officials and President $\mathrm{Hu}$ Jintao have been positive, judging by all the opinions expressed by the African authorities. Consequently, as I say, I am delighted at this new connection between Africa and China. ${ }^{(33)}$

This satisfaction surprised many observers, who were expecting a more critical appraisal of Beijing's role from the former French head of state. For France, China's presence has the advantage of fostering economic development by bringing in low-cost consumer items such as machine tools (tractors, agricultural machines, etc.). The PRC is also playing a role in passing on agricultural techniques. In this sense, French policy is in line with the views expressed by the OECD,${ }^{(34)}$ which takes a rather favourable view of China's investment in Africa ${ }^{(35)}$ given that economic development is considered to be a precondition of Africa's democratisation. President Chirac emphasised that cooperation with China can prove beneficial for African countries, in spite of increasing criticism in Africa ${ }^{(36)}$ and Europe ${ }^{(37)}$ directed at Beijing's African diplomacy, which are not really justified in the light of China's still limited presence on the African continent.

Animosity towards China can be explained by several factors. In the first place, Chinese firms have invested in sectors such as the construction industry and public works where their achievements are there for all to behold (roads, dams, bridges). In Angola, the majority of Chinese investments are in the construction industry. This approach is in response to a demand by African countries after the West began to slow down the pace of "white elephant" infrastructure development in the 1980s following several spectacular failures. The modest engagement of local workers and the huge number of Chinese expatriates is a regular source of ill-feeling, and the rapid growth of China's trade and investment in Africa feeds into this feeling of "Chinese colonisation." Chinese investments are concentrated in raw materials (mines, energy sector), but also in the manufacture of everyday consumer items (loincloths, tractors). Chinese competition greatly weakens local African capitalism. In particular, China's presence is evident through the thousands of its nationals living in Africa (thought to be around 750,000), ${ }^{(38)}$ well above the number of Westerners; it is estimated that in December 2007 about 155,000 French nationals were settled in Africa, half of whom were in Algeria, Morocco, and Tunisia, while in 2006, 22,000 Chinese were living in Angola, ${ }^{(39)}$ most of them working for a Chinese company. China's presence in Africa is indisputable, but it must be properly understood. Here, as elsewhere, the PRC's position is relative to its standing worldwide.

\section{- Translated by Peter Brown}

33. Press conference, 16 February 2007, source: http://www.elysee.fr/.

34. OECD Report, "The Rise of China and India. What's in it for Africa?", 2006.

35. Cf. also Chris Alden, who stresses that China-Africa relations are complex, involving reciprocal interests. Chris Alden, China in Africa, Partner, Competitor or Hegemon?, Zed Books, 2007.

36. The journalist Noé Ndjebet Massoussi, from the Cameroon daily Le Messager, $\mathrm{n}^{\circ} 2301$ 31 January 2007 , p. 3, relates the failures of the roads built by China and concludes by asking, "Isn't the image that China used to be stuck with, that of a country doing shoddy work that won't last any time at all, overtaking these other works carried out by representatives of the Middle Empire?"

37. In November 2007, the European Parliament adopted a resolution entitled "Chinese policy and its effects on Africa," which "points out that China's untrammelled investment in African countries which are subject to the bad governance of oppressive regimes is contributing to perpetuating human rights' violations and merely serves to reinforce such bad governance."

38. Alden, op.cit, p. 121.

39. Op cit., p. 23. 